\title{
Computational Propaganda in Hashtag Activism
}

\section{Komputasi Propaganda dalam Aktivisme Tagar}

\author{
Andhika Kurniawan Pontoh ${ }^{1}$ \\ ${ }^{1}$ Fakultas Ilmu Komunikasi, Universitas Indonesia, J1. Salemba Raya No.4, Jakarta Pusat* \\ Email: andhika.kurniawan@ui.ac.id
}

Masuk tanggal : 21-02-2021, revisi tanggal : 27-08-2021, diterima untuk diterbitkan tanggal : 16-09-2021

\begin{abstract}
The hashtag (\#) has an important role in gathering Internet users' support for opinion and value. Computational propaganda has an important role in hashtag activism. This study wants to examine the role of computational propaganda actors such as anonymous political accounts, fake accounts and bot in social media that is able to mobilize the public and also increase the impression of Twitter audiences. The trend of Twitter hashtag activism \#BebaskanIBHRS and \#NegaraDamaiTanpaFPI began with the arrest of the chairman of the Islamic Defenders Front (FPI) Habib Rizieq Shihab (HRS); the two trending hashtags massively influenced public opinion on Twitter on December 13-14 2020. This study uses a sample of 1000 tweets or conversations on each hashtags and uses Social Network Analysis (SNA) with the Netlytic tool which is able to provide quantitative values of communication networks, through the social network structure of \#BebaskaniBHRS and \#NegaraDamaiTanpaFPI. This study reveals how the network structure and what factors are carried out by anonymous political actors in carrying out computational propaganda. The results of this study reveal the hashtags activism \#BebaskaniBHRS is much more capable of mobilizing the public and is able to generate greater impressions than \#NegaraDamaiTanpaFPI. This is because \#BebaskaniBHRS has a computational propaganda message in the form of a loaded language with a clear frame and the choice of words directly invites the Twitter public to get involved through a retweet another finding in this research shows computational propaganda movement in hashtag activism was carried out by large groups consisting of anonymous accounts and bot accounts on other side online media coverage about the trending of these hashtag's activism was also able to increasing public attention.
\end{abstract}

Keywords: computational propaganda, hashtag activism, Social Network Analysis (SNA)

\begin{abstract}
Abstrak
Tagar (\#) memiliki peran penting dalam mengumpulkan dukungan pengguna Internet terhadap suatu opini dan nilai. Komputasi propaganda memiliki peran penting dalam aktivisme tagar. Penelitian ini ingin mengkaji peran aktor komputasi propaganda seperti akun anonim politik, akun palsu dan bot di media sosial yang mampu memobilisasi publik dan juga meningkatkan kesan khalayak Twitter. Tren aktivisme tagar Twitter \#BebaskanIBHRS dan \#NegaraDamaiTanpaFPI dimulai dengan penangkapan ketua Front Pembela Islam (FPI) Habib Rizieq Shihab (HRS); kedua tagar yang sedang trending tersebut secara masif memengaruhi opini publik di Twitter pada 13-14 Desember 2020. Penelitian ini menggunakan sampel 1000 tweet atau percakapan pada masing-masing tagar serta menggunakan Social Network Analysis (SNA) dengan alat Netlytic yang mampu
\end{abstract}


memberikan nilai kuantitatif jaringan komunikasi. Melalui struktur jejaring sosial \#BebaskaniBHRS dan \#NegaraDamaiTanpaFPI, kajian ini mengungkap seperti apa struktur jaringan komunikasi dan hal apa saja yang dilakukan oleh aktor politik anonim dalam melakukan komputasi propaganda. Hasil penelitian ini mengungkapkan bahwa aktivisme tagar \#BebaskaniBHRS jauh lebih mampu memobilisasi publik dan mampu menghasilkan impresi yang lebih besar dibandingkan \#NegaraDamaiTanpaFPI. Hal ini dikarenakan \#BebaskaniBHRS memiliki pesan komputasi propaganda dalam bentuk bahasa yang sarat dengan bingkai yang jelas dan pilihan kata secara langsung mengajak publik Twitter untuk terlibat melalui retweet.Temuan lain dalam penelitian ini menunjukkan gerakan komputasi propaganda dalam aktivisme tagar dilakukan oleh kelompok besar yang terdiri dari akun anonim dan akun bot di sisi lain liputan media daring tentang tren aktivisme tagar ini juga mampu meningkatkan atensi publik.

Kata Kunci: aktivisme tagar, komputasi propaganda, Social Network Analysis (SNA)

\section{Pendahuluan}

Penggunaan media sosial sebagai sarana komunikasi politik di Indonesia adalah hal yang esensial, berdasarkan data terbaru yang dikeluarkan oleh We Are Social menunjukkan bahwa pengguna Internet di Indonesia pada tahun 2020 sebanyak 175, 4 Juta pengguna, data tersebut juga menunjukkan adanya kenaikan $17 \%$ atau 25 juta pengguna internet dibandingkan pada tahun sebelumnya. Laporan tersebut juga menunjukkan jumlah pengguna media sosial di Indonesia sebanyak 160 Juta pengguna yang jika dibandingkan dengan jumlah pengguna pada tahun sebelumnya terjadi peningkatan sebesar 10 juta pengguna, dalam laporan yang sama mengungkapkan $56 \%$ dari total pengguna media sosial memiliki akun Twitter (Hootsuite, 2020). Twitter adalah salah satu media sosial yang mampu menyuarakan aspirasi demokrasi. Twitter adalah media demokrasi karena Twitter dapat menyuarakan aktivasi demokrasi dan Twitter dapat menjadi sumber informasi berita politik (Small, 2011). Salah satu fitur dalam Twitter adalah tagar (tagar), fitur ini mampu mengumpulkan dan mengorganisasikan informasi spesifik di Twitter, dengan menggunakan tagar suatu informasi dalam bentuk tweet dapat diterima oleh lebih banyak pengguna (Fitton et al., 2010).

Tagar memiliki peran penting dalam mengumpulkan dukungan pengguna Internet terhadap suatu pemikiran dan nilai. Aktivisme Tagar didefinisikan sebagai suatu aksi memperjuangkan atau mendukung suatu tujuan dengan penggunaan tagar sebagai saluran utama untuk meningkatkan kesadaran akan suatu masalah dan mendorong debat melalui media sosial (Tombleson \& Wolf, 2017). Beberapa penelitian menunjukkan bahwa tagar berfungsi sebagai wahana untuk menciptakan kesadaran dan diskusi, menyebarkan ide individu membuat afiliasi yang lebih baik dengan komunitas, dan mengintegrasikan sumber daya komunikasi dari Internet (Xiong et al., 2019). Peneliti lain berpendapat bahwa jaringan aktivis tagar dapat memfasilitasi pembentukan kebijakan, perubahan sosial dan demokrasi (Holtzhausen, 2009). Hallahan pada penelitiannya juga menemukan aktivisme melalui platform online mencerminkan proses pembingkaian (framing) yang memungkinkan organisasi aktivis berkontribusi pada pembentukan sikap dan keyakinan publik seputar masalah yang menonjol (Hallahan, 1999). 
Tagar memungkinkan pengguna menyaring hiruk-pikuk percakapan online untuk mengidentifikasi topik dan percakapan pribadi yang relevan. Kemampuan pengguna untuk mengakses dan berpartisipasi dalam percakapan seputar masalah sosial dan politik telah menghasilkan bentuk aktivisme tagar yang merupakan tindakan memperjuangkan atau mendukung suatu tujuan dengan menggunakan tagar sebagai saluran untuk meningkatkan kesadaran tentang suatu masalah dan mendorong perbedaan pendapat melalui media sosial. (Tombleson \& Wolf, 2017). Tren tagar Twitter \#BebaskanIBHRS dan \#NegaraDamaiTanpaFPI bermula pada penangkapan pemimpin Front Pembela Islam (FPI) Habib Riziq Shihab (HRS). Kasus ini bermula setelah penyidik Polda Metro Jaya menetapkan Rizieq Shihab sebagai tersangka terkait dugaan pelanggaran protokol kesehatan kerumunan massa di Petamburan, Jakarta Pusat pada Sabtu 14 November 2020. \#BebaskanIBHRS telah menjadi trending topik Twitter semenjak 13 Desember 2020, para pendukung tagar ini memberikan dukungan dengan meminta polisi segera membebaskan Habib Rizieq mulai dari puisi hingga tayangan video-pun dilakukan (Setiyadi, 2020). Sedangkan tagar \#NegaradamaitanpaFPI secara bersamaan menjadi tren topik pada waktu yang sama dan menjadi rival \#BebaskanIBHRS (Sholehudin, 2020).

Penelitian tentang gerakan sosial daring telah menunjukkan peran jaringan digital dalam menginformasikan para aktivis politik (Gerbaudo, 2012). Gerakan sosial online menyebarkan kerangka kerja politik (Castells, 2015) dan desentralisasi kepemimpinan (González-Bailón et al., 2014). Wacana atau isu yang dimediasi secara digital dapat diasosiasikan sebagai cerminan mobilisasi dalam aksi politik luring (Polletta \& Lee, 2006). Aktivisme tagar merupakan bentuk gerakan diskursif di media sosial yang disatukan melalui kata, frasa, atau kalimat yang diberi tagar yang mampu menciptakan wacana publik. Aktivisme tagar terjadi ketika adanya unggahan dengan jumlah banyak di media sosial yang memiliki kata atau kalimat tagar yang sama. Tagar tersebut memiliki nilai-nilai sosial maupun politis. Aktivisme tagar juga merupakan cara yang potensial untuk meningkatkan kesadaran advokasi akan isu tertentu, hal ini dapat terjadi karena aktivisme tagar tidak memerlukan "gatekeepers" untuk menyampaikan ke publik (J. Bennett, 2014).

Aktivisme tagar didefinisikan sebagai suatu aksi memperjuangkan atau mendukung suatu tujuan dengan penggunaan tagar sebagai saluran utama untuk meningkatkan kesadaran akan suatu masalah dan mendorong debat melalui media sosial (Tombleson \& Wolf, 2017). Aktivisme tagar yang baik harus memiliki karakter narasi yang jelas. Aktivisme tagar dapat terjadi ketika sejumlah besar komentar dan retweet muncul di Twitter sebagai tanggapan terhadap kata, frasa, atau kalimat dengan tagar oleh karena itu narasi adalah hal yang penting aktivisme tagar

Propaganda komputasi adalah istilah dan fenomena yang mencakup kesalahan informasi digital dan upaya manipulasi pada era digitalisasi. Propaganda komputasi didefinisikan sebagai penggunaan algoritma, otomatisasi, dan kurasi manusia untuk dengan sengaja mendistribusikan informasi yang menyesatkan melalui jaringan media sosial (Woolley \& Howard, 2016). Propaganda komputasi melibatkan robot/bot, akun palsu dan akun anonim yang memanipulasi opini publik 
di berbagai platform media sosial dan jaringan perangkat. Aktor politik anonim memanfaatkan elemen kunci dari propaganda komputasi seperti menginformasikan berita palsu, kampanye disinformasi yang terkoordinasi dan kelompok troll untuk menyerang atau membela isu seperti hak asasi manusia, kelompok masyarakat sipil, dan jurnalis. Propaganda komputasi adalah aktivisme digital baru yang paling kuat untuk membangun atau, bahkan menghancurkan demokrasi (Woolley \& Howard, 2016). Komputasi propaganda merupakan kegiatan terkoordinasi untuk menyampaikan pesan dengan memanfaatkan botnets atau kelompok automasi robot di media sosial (J Zhang et al., 2018).

Komputasi propaganda berisi pesan-pesan yang yang dibangun berdasarkan retorika dan psikologi emosi seperti loaded language yang merupakan pemilihan kata untuk membangkitkan emosi dan memanfaatkan stereotip, flag waving ekspresi menampilkan semangat patriot populis, Menggunakan slogan, appeal to authority menunjukkan kebenaran karena adanya otoritas, red herring yang merupakan menunjukkan data yang tidak relevan, straw men atau melakukan interpretasi yang salah pada opini seseorang, black-and-white fallacy yang merupakan tindakan menunjukkan dua alternatif sebagai satu-satunya kemungkinan dan whataboutism atau teknik retorika dengan memutarbalikkan kritik dengan mengungkapkan isu lain yang tidak relevan,tetapi setara (Da San Martino et al., 2020). Penelitian sebelumnya telah menemukan bahwa media sosial menyukai konten sensasional, terlepas dari apakah konten telah diperiksa fakta atau berasal dari sumber yang dapat diandalkan (Del Vicario et al., 2016). Twitter adalah media sosial yang sering digunakan untuk melakukan komputasi propaganda, para peneliti menemukan banyaknya akun bot sosial dan akun otomatis (Lokot \& Diakopoulos, 2016). Para peneliti mencatat bahwa API Twitter yang fleksibel dengan banyak aplikasi dan layanan pihak ketiga membuat bot secara mudah untuk berkembang biak, hal ini membuat peningkatan otomatisasi dapat menciptakan pedang bermata dua karena bot dengan tujuan baik akan melambungkan jumlah pengguna Twitter dan menghasilkan sejumlah besar tweet bermanfaat, sementara ada kemungkinan bahwa bot yang dapat memanipulasi tagar dan menyebarkan spam (Chu et al., 2010).

Trolling dan akun Palsu merupakan elemen penting dari kehidupan politik daring. trolling adalah kegiatan yang sengaja memancing orang untuk memunculkan respons emosional (Woolley \& Howard, 2016). Berita bohong yang tersebar luas melalui platform media sosial dalam banyak kasus dapat dianggap sebagai bentuk propaganda komputasi, bot dan akun palsu sering menjadi alat utama dalam mendorong disinformasi ini di seluruh situs seperti Twitter, dan Facebook (Woolley \& Howard, 2016). Forum Ekonomi Dunia mengidentifikasi penyebaran cepat informasi yang salah secara online sebagai salah satu dari 10 bahaya teratas bagi masyarakat (Vis, 2014). Penelitian mengenai aktivasi digital melalui tagar telah dilakukan oleh beberapa peneliti, (Eriyanto,2020) mengungkapkan bagaimana kedua tagar \#BubarkanKPAI dan \#KamiBersamaKPAI mampu memobilisasi pengguna Twitter. (Neudert, 2017) mengungkapkan bagaimana propaganda komputasi Twitter memiliki peran penting dalam mobilisasi khalayak di Jerman. (Gorwa, 2017) mengungkapkan bagaimana komputasi propaganda melalui berita bohong mampu memengaruhi dunia politik 
polandia dan (Arnaudo, 2017) menjelaskan bagaimana robot Twitter dalam \#Vemprademocracia memengaruhi demokrasi rakyat Brazil.

Penelitian ini ingin menggambarkan bagaimana peran aktor komputasi digital berupa aktor politik anonim atau akun palsu di media sosial yang mampu memobilisasi publik dan meningkatkan impresi khalayak Twitter melalui struktur jaringan sosial \#BebaskaniBHRS dan \#NegaradamaitanpaFPI. Pada penelitian ini menggunakan analisis jaringan sosial yang mampu menghasilkan gambaran struktur jaringan pada masing-masing tagar. Melalui analisis jaringan sosial, penelitian ini memberikan gambaran baru bahwa komputasi propaganda di media sosial Twitter dilakukan melalui kelompok-kelompok besar yang dipimpin oleh aktor sentral berupa akun anonim atau troll dengan anggota akun bot.

\section{Metode Penelitian}

Untuk mengetahui pesan komputasi propaganda pada tagar \#BebaskaniBHRS dan \#NegaradamaitanpaFPI peneliti melakukan analisis isi sintaksis yang merupakan metode unit informasi yang merupakan elemen yang secara khusus terkait dengan makna dan produksi konten. Unit konten mewakili elemen yang didefinisikan secara independen dari studi dan sering kali oleh pembuat konten (Riffe et al.,2019). Pada penelitian ini, peneliti menggunakan metode operasionalisasi konten sintaksis yang merupakan unit diskret dalam bahasa atau media. Satuan sintaksis yang paling sederhana dalam bahasa adalah kata, kalimat, paragraf artikel dan buku (Riffe et al., 2019). Peneliti melakukan pengelompokan pesan yang didasarkan pada kategorisasi isi pesan komputasi propaganda yang diungkapkan pada penelitian sebelum oleh Da San Martino et al., 2020). Pemilihan kunci kata didasarkan pada 50 frekuensi kata teratas dalam 1000 twitt \#BebaskaniBHRS dan 1000 twitt \#NegaradamaitanpaFPI.

Untuk menjawab bagaimana aktivisme tagar \#BebaskaniBHRS dan \#NegaradamaitanpaFPI mampu memberikan atensi publik, peneliti menggunakan Social Network Analysis (SNA) yang merupakan penyelidikan terhadap pola hubungan antaraktor sosial, serta pola hubungan antaraktor dan kelompok. Analisis jaringan komunikasi adalah metode yang berusaha menjelaskan jaringan sosial dan struktur jaringan, jaringan didefinisikan sebagai organisasi aktor yang memiliki hubungan dengan aktor lainnya dalam tipe hubungan tertentu. Aktor (Node) dapat berupa individu, kelompok atau organisasi, negara perusahaan Link (edge) adalah hubungan atau relasi antaraktor yang dilambangkan oleh satu garis yang menghubungkan aktor satu dengan aktor Lainnya (Breiger, 2004). Penelitian ini menggunakan pendekatan analisis jaringan komunikasi deskriptif di mana penelitian ini ingin menjelaskan struktur dan aktor-aktor dalam jaringan dalam tagar \#BebaskaniBHRS dan \#NegaradamaitanpaFPI. Pendekatan jaringan komunikasi adalah metode yang dipakai untuk melihat struktur komunikasi dan posisi aktor (orang, organisasi, lembaga) dalam struktur komunikasi (Eriyanto, 2014). Untuk mengetahui posisi aktor peneliti mencari nilai Degree centrality yang merupakan jumlah hubungan yang dimiliki oleh aktor dan Betwenness centrality adalah seberapa sering sebuah aktor dilewati oleh aktor lain untuk menuju ke aktor 
tertentu di dalam jaringan. Nilai ini menjelaskan penentuan peran aktor yang menjadi jembatan interaksi di dalam jaringan (Junlong Zhang \& Luo, 2017).

Untuk mengetahui nilai hubungan dalam jaringan peneliti mencari nilainilai kuantitatif densitas (kepadatan) adalah ukuran yang menggambarkan kerapatan dari sebuah jaringan, sebuah jaringan disebut mempunyai kepadatan atau kerapatan yang tinggi jika anggota (aktor / node) dalam jaringan saling berinteraksi satu sama lain. Nilai diameter adalah pengukuran yang menunjukkan jarak paling jauh seorang aktor terhubung dengan aktor lain. Jarak adalah berapa langkah (tahap) yang memungkinkan seorang aktor bisa menghubungi aktor lain dalam jaringan. Nilai Centrality digunakan untuk mengukur rata-rata derajat sentral dari semua node dalam jaringan. Jaringan memiliki nilai sentralisasi tinggi lebih dekat dengan 1 menunjukkan ada beberapa peserta sentral yang mendominasi aliran informasi dalam jaringan. Jika nilai dekat dengan 0 dianggap terdesentralisasi di mana informasi mengalir lebih bebas di antara banyak peserta. Reciprocity adalah nilai yang menunjukkan hubungan yang menunjukkan komunikasi dua arah, nilai yang tinggi menunjukkan banyak peserta memiliki percakapan dua arah. Modularity adalah nilai yang menunjukkan adanya kelompok dalam jaringan, nilai modularitas lebih dari 0,5 menunjukkan bahwa jaringan terdiri dari kelompokkelompok besar (Gruzd, 2016).

Peneliti mengambil sampel 1000 Tweet pada tagar \#BebaskaniBHRS dan 1000 tweet \#NegaradamaitanpaFPI pada 13 Desember 2020 yang dikumpulkan menggunakan alat Netlytic, Langkah awal peneliti mencari kata kunci \#BebaskaniBHRS dan \#NegaradamaitanpaFPI masing- masing dari dua kata kunci tersebut menghasilkan gambaran struktur jaringan, gambaran dua jaringan ini dapat menggambarkan adanya kelompok-kelompok yang terlibat dalam percakapan pada dua tagar tersebut. Struktur jaringan ini juga dapat menggambarkan aktor atau akun Twitter mana saja yang mendominasi percakapan dan mampu memengaruhi dan menyebarluaskan pesan dalam jaringan tagar tersebut, selain gambar struktur jaringan Netlytic juga mengekstrak pesan-pesan yang disampaikan oleh akun-akun pada struktur jaringan, dari pesan-pesan tersebut dapat terdeksi pesan yang unik (tidak berulang) dan mana pesan yang cenderung berulang dan dilakukan oleh salah satu aktor, indikasi ini peneliti menganggap sebagai deteksi bot yang melakukan penyebaran informasi, selain itu peneliti akan melakukan verifikasi ulang terhadap akun yang menjadi suspek bot dengan menggunakan alat Botometer. Nilai botmeter diatas 3 mengindikasikan akun tersebut merupakan akun bot (Sayyadiharikandeh et al., 2020). 


\section{Hasil Penemuan dan Diskusi}

\section{\#BebaskaniBHRS}

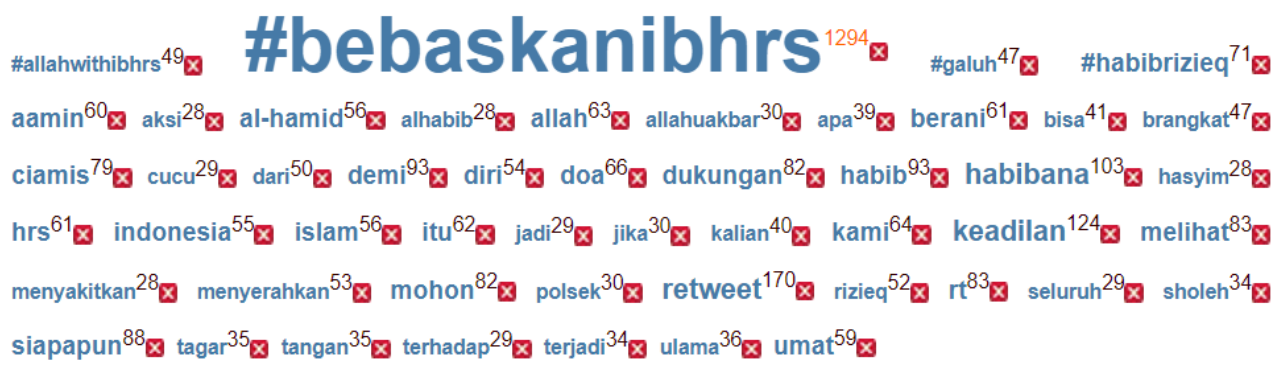

Gambar 1: 50 Kata teratas dalam jaringan \#BebaskaniBHRS

(Sumber: Dokumentasi Peneliti)

Berdasarkan data yang diambil melalui mediatoolkit, \#BebaskanIBHRS mampu menghasilkan impresi sebanyak 1,370,501 impresi jauh lebih tinggi dibandingkan \#NegaradamaitanpaFPI yang hanya mampu mendapatkan 131,608 impresi dalam kurun waktu periode 2 Desember 2020- 1 Januari 2020, hal ini mengindikasikan bahwa \#BebaskanIBHRS dinilai jauh lebih baik dan mampu memobilisasi publik untuk terlibat dalam percakapan, dengan mengambil sampel 1000 tweet pada 13 Desember 2020 yang merupakan periode puncak percakapan dan keterlibatan. Pada 50 frekuensi kata terbanyak pada aksi tagar \#BebaskaniBHRS menunjukkan banyaknya kata-kata berupa dukungan, doa dan terdapat aksi tagar lain berupa tagar seperti \#Allahwithibhrs, \#galuh, \#habibizieq.

Berdasarkan analisis isi sintaksis kategori pesan komputasi propaganda menunjukkan bahwa gerakan tagar \#BebaskaniBHRS terdiri dari kategori pesan komputasi propaganda mayoritas berupa Flag-waving dengan jumlah 998 tweet yang menggambarkan \#BebaskaniBHRS terdiri dari pesan-pesan berupa ekspresi menampilkan semangat patriot populis Islam yang diwakilkan melalui penggunaan kata \#Allahwithibhrs, Islam, \#habibrizieq,Umat, Alhabib dan gaungkan tagar.

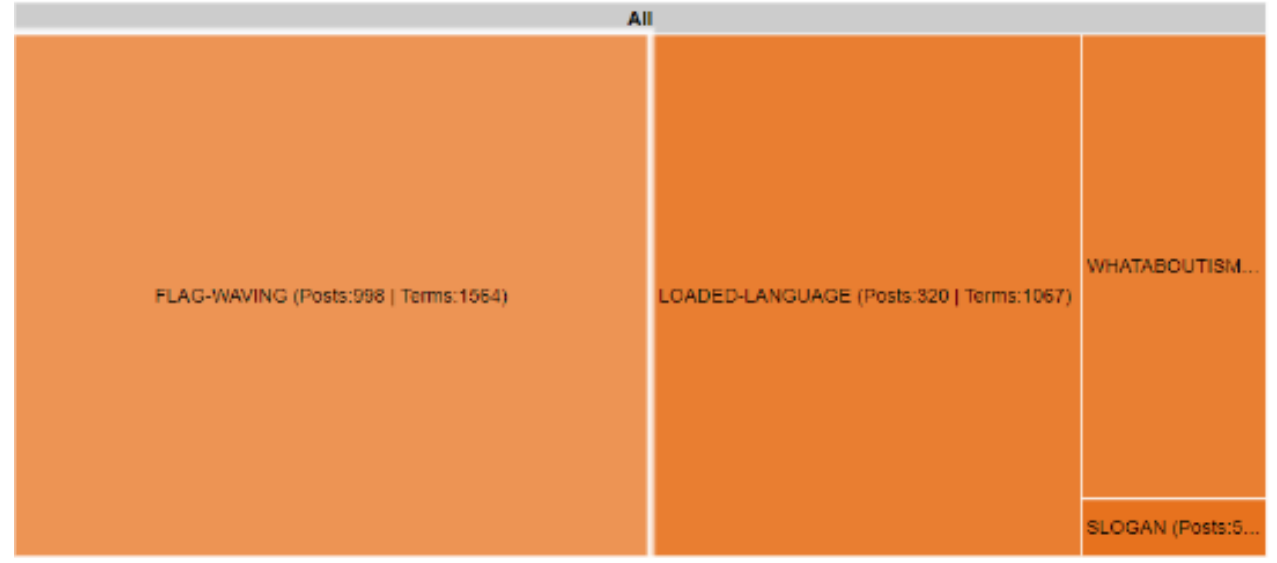

Gambar 2: Analisis sintaksis \#BebaskaniBHRS

(Sumber: Dokumentasi Peneliti) 
Gerakan aktivisme \#BebaskaniBHRS memiliki pesan komputasi propaganda loaded language yang terdiri dari kata untuk membangkitkan emosi seperti penggunaan kata: mohon, retweet, dukungan, berani, menyebarkan, Allahuakbar, menyakitkan, menyerahkan pemilihan kata ini membangkitkan emosi para pengguna Twitter untuk turut serta melakukan dukungan pada gerakan \#BebaskaniBHRS. Gerakan tagar \#BebaskaniBHRS terdapat pesan komputasi propaganda berupa Whataboutism diwakilkan melalui kata Al-Hamid, Al-Habib, habibana dan Cucu yang menggambarkan adanya penonjolan isu lain yang tidak relevan dengan kasus penangkapan, yaitu berupa penekanan bahwa Habib Rizieq adalah cucu dari Habib hasyim Al-hamid. Selain itu, terdapat pesan komputasi propaganda berupa slogan populi Islam direpresentasikan melalui penggunaan kata Allahuakbar. Pesan-pesan komputasi propaganda tersebut dikoordinasikan melalui akun-akun yang tergabung dalam kelompok botnets dalam aktivasi tagar \#BebaskaniBHRS. Berdasarkan hasil Social Network Analysis (SNA) mengungkapkan bahwa nilai modularity dari struktur jaringan \#BebaskaniBHRS memiliki nilai modularity sebesar 0.562100 yang mengindikasikan bahwa jaringan \#BebaskaniBHRS terdiri dari kelompok-kelompok besar yang ditandai oleh beberapa warna berbeda dalam gambar struktur jaringan. Hasil pengamatan Netlytic mengungkapkan bahwa \#BebaskaniBHRS memiliki diameter empat, hal ini berarti terdapat empat langkah sebagai jarak paling jauh seorang aktor terhubung dengan aktor lain, hal ini juga berarti hanya empat langkah penghubung yang harus dicapai aktor lain di luar dalam gerakan aktivisme digital \#BebaskaniBHRS agar dapat terpapar pesan tersebut.

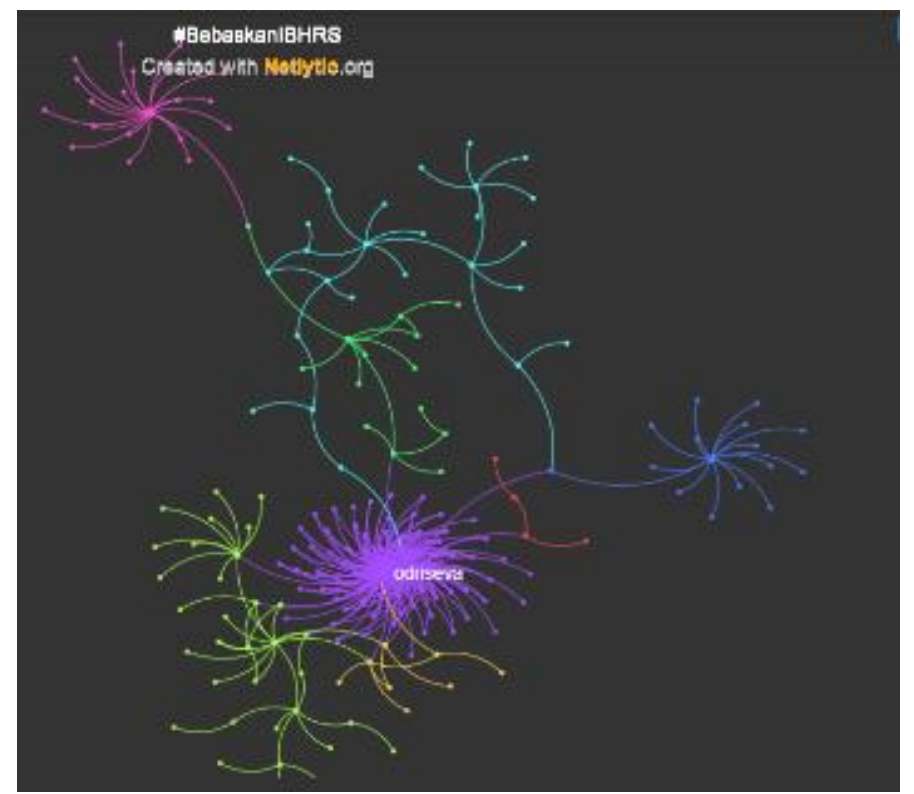

Gambar 3: Struktur Jaringan sosial \#BebaskaniBHRS (Sumber: Dokumentasi Peneliti)

Nilai density dalam struktur jaringan komunikasi \#BebaskaniBHRS memiliki nilai 0.007158 yang diinterpretasikan jauh dari angka satu hal ini berarti bahwa jaringan \#BebaskaniBHRS tidak rapat dan pesan hanya terjadi diantara 
kelompok-kelompok besar. Nilai sentralita s\#BebaskaniBHRS dalam jaringan adalah 0.161000 hal ini mengindikasikan bahwa alur pesan dalam jaringan bersifat terdesentralisasi pada kelompok-kelompok besar serta \#BebaskaniBHRS memiliki nilai Reciprocity 0.000000 yang mengindikasikan bahwa para akun dalam jaringan hanya melakukan komunikasi satu arah dalam kelompok-kelompok.
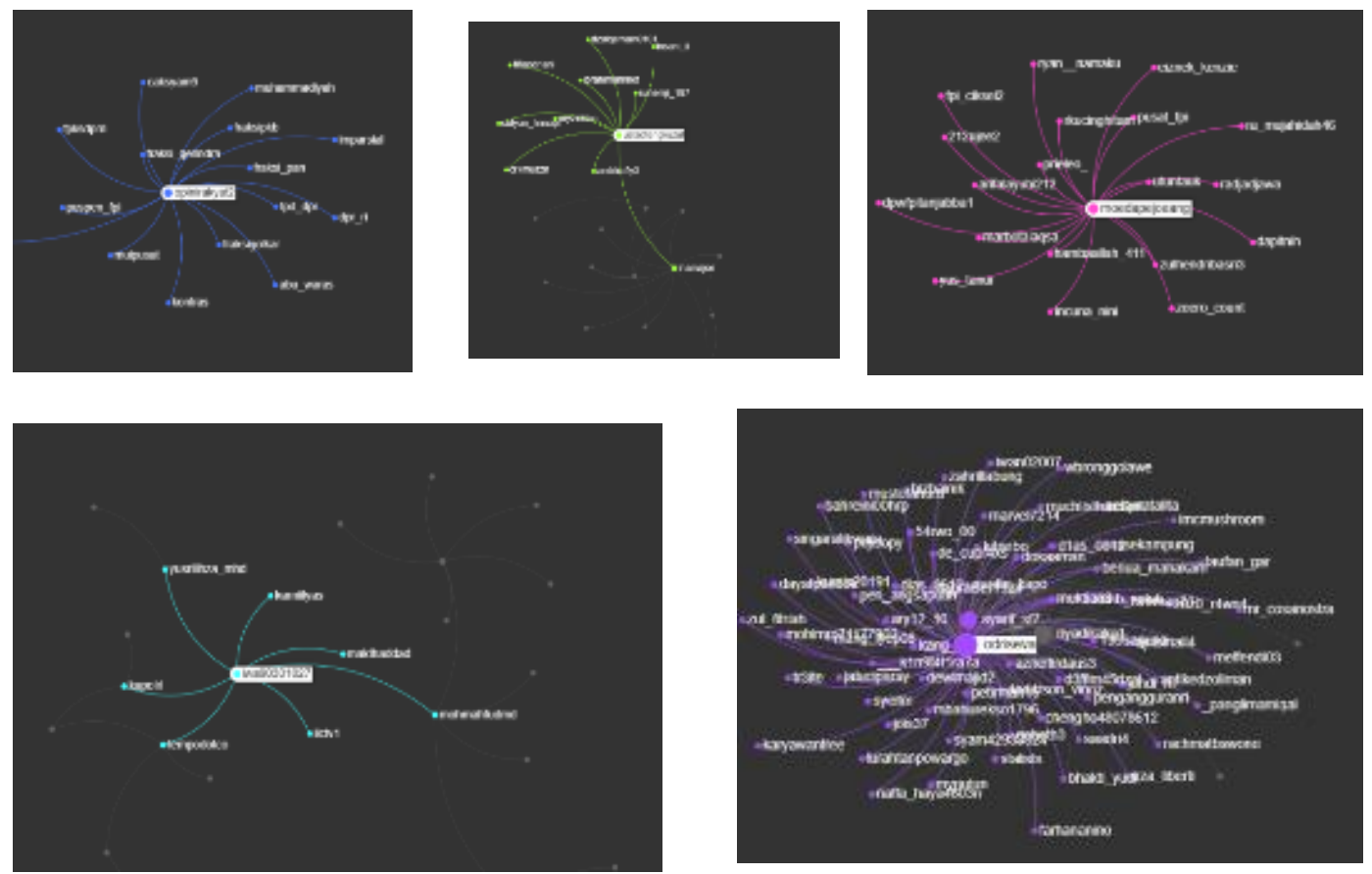

Gambar 4: Kelompok jaringan sosial \#BebaskaniBHRS (Sumber: Dokumentasi Peneliti)

Komunikasi satu arah dalam kelompok-kelompok jaringan \#BebaskaniBHRS dilakukan oleh akun-akun sentral yang menyebarluaskan pesanpesan komputasi propaganda berdasarkan hasil analisis jaringan sosial mengungkapkan bahwa terdapat akun-akun yang berpengaruh dalam penyebaran informasi, tokoh-tokoh ini secara aktif melakukan komunikasi keluar (outdegree) dengan tokoh lain, aktor-aktor seperti odriseva, yennirachman74, dan rqthea adalah tokoh-tokoh yang sering menghubungkan diantara aktor satu dengan lain nya hal ini terindikasikan atas nilai betweenesscentrality yang cukup tinggi.

Tabel 1. Aktor-aktor berpengaruh dalam struktur jaringan \#BebaskaniBHRS

\begin{tabular}{cccccc}
\hline Akun media sosial & indegr & outdegr & Degre & Centrality & betweenesscentralit \\
& $e e$ & $e e$ & $e$ & & $y$ \\
\cline { 2 - 6 } odriseva & 3 & 74 & 77 & 1 & 0.000219 \\
riyadikaka1 & 0 & 54 & 54 & 1 & 0 \\
syarif_sf7 & 0 & 50 & 50 & 2 & 0 \\
moedapejoeang & 0 & 20 & 20 & 1 & 0 \\
yennirachman74 & 1 & 18 & 19 & 1 & 0.000041 \\
sabtumalam_8919 & 0 & 18 & 18 & 1 & 0
\end{tabular}




\begin{tabular}{cccccc}
\hline opinirakyat2 & 0 & 15 & 15 & 1 & 0 \\
inamajoe & 0 & 12 & 12 & 1 & 0 \\
ustadtengkuzul & 11 & 0 & 11 & 0 & 0 \\
rqthea & 1 & 7 & 8 & 1 & 0.000014 \\
\hline
\end{tabular}

Untuk membuktikan adanya akun trolling politik yang bekerja dalam memobilisasi pergerakan \#BebaskaniBHRS peneliti mengambil salah sample melalui gerakan yang dilakukan oleh akun paling penghubung dalam jaringan \#BebaskaniBHRS, yaitu odriseva pada gambar lima terlihat gerakan akun odriseva melakukan hubungan ke berbagai akun politik melalui mention dan menempatkan tagar \#BebaskaniBHRS pada pesan, proses outdegree yang dilakukan oleh odriseva mampu memperluas jaringan \#BebaskaniBHRS. Berdasarkan nilai botometer mengindikasikan bahwa odriseva memiliki nilai Echo-chamber tinggi 4.1 yang mengindikasikan bahwa akun odriseva sering kali memiliki melalukan penyebarluasan pesan-pesan politik secara masif.

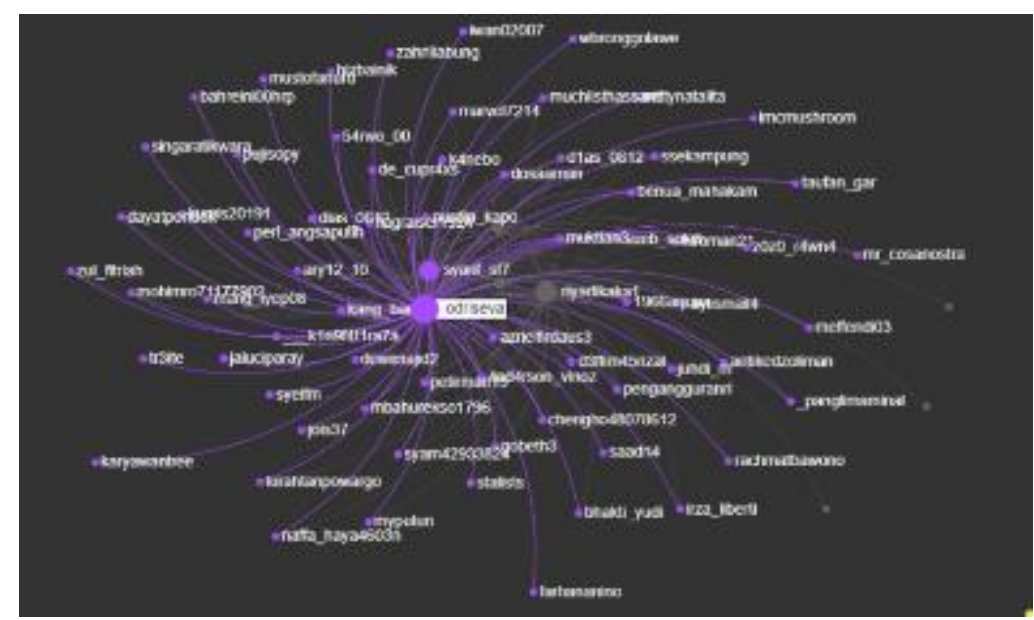

Gambar 5: Gerakan massif trolling odriseva pada (Sumber: Dokumentasi Peneliti)

Untuk membuktikan adanya akun bot pada jaringan \#BebaskaniBHRS, peneliti mengambil sampel melalui pesan komputasi propaganda Whataboutism dalam jaringan \#BebaskaniBHRS. Berupa pengalihan isu melalui twit yang dilakukan oleh akun anonim MCAOps. Berdasarkan nilai Botometer mendekati lima dan rasio retweet akun lebih dari 90\%, maka dapat disimpulkan bahwa akun Oyoy71234464, pinoy4567420, NangGo5, AlfatehAzzam, zidan2002 , Orini_99 dan umam_chaerul adalah akun bot yang secara automasi melakukan retweet pesan RT @ MCAOps: Habib hasyim Al-hamid, cucu Alhabib Sholeh Al-hamid Tanggul: "Kami ke Polsek untuk protes kepada apa yang terjadi terhadap Habib Rizieq. Penangkapan HRS menyakitkan umat Islam. Mudah-mudahan aksi ini bisa diikuti di seluruh Indonesia. \#BebaskanIBHRS. 
Tabel 2. Akun-akun bot pada aktivisme tagar \#BebaskaniBHRS

\begin{tabular}{|c|c|c|c|c|}
\hline Akun & Pesan Komputasi Propaganda & $\begin{array}{l}\text { Rasio } \\
\text { Retweet }\end{array}$ & $\begin{array}{l}\text { Botomet } \\
\text { er }\end{array}$ & $\begin{array}{l}\text { Interpret } \\
\text { asi }\end{array}$ \\
\hline Oyoy 71234 & & & & Akun \\
\hline 464 & & $99 \%$ & 4.6 & Bot \\
\hline $\begin{array}{l}\text { pinoy } 45674 \\
20\end{array}$ & RT @MCAOps: Habib hasyim & $100 \%$ & 4.8 & $\begin{array}{c}\text { Akun } \\
\text { Bot }\end{array}$ \\
\hline NangGo5 & $\begin{array}{l}\text { Al-hamid, cucu Alhabib Sholeh } \\
\text { Al-hamid Tanggul: "Kami ke }\end{array}$ & $99 \%$ & 4.1 & $\begin{array}{c}\text { Akun } \\
\text { Bot }\end{array}$ \\
\hline $\begin{array}{l}\text { AlfatehAzza } \\
m\end{array}$ & $\begin{array}{l}\text { Polsek untuk protes kepada apa } \\
\text { yang terjadi terhadap Habib }\end{array}$ & $92 \%$ & 4.2 & $\begin{array}{c}\text { Akun } \\
\text { Bot }\end{array}$ \\
\hline zidan2002 & $\begin{array}{l}\text { Rizieq. Penangkapan HRS } \\
\text { menyakitkan umat Islam. }\end{array}$ & $100 \%$ & 4.7 & $\begin{array}{c}\text { Akun } \\
\text { Bot }\end{array}$ \\
\hline Orini_99 & \#BebaskanIBHRS & $100 \%$ & 4.8 & $\begin{array}{l}\text { Akun } \\
\text { Bot }\end{array}$ \\
\hline $\begin{array}{l}\text { umam_chae } \\
\text { rul }\end{array}$ & & $100 \%$ & 3.8 & $\begin{array}{c}\text { Akun } \\
\text { Bot }\end{array}$ \\
\hline
\end{tabular}

\section{\#NegaradamaitanpaFPI}

Berdasarkan data yang diambil melalui Mediatoolkit, \#NegaradamaitanpaFPI mampu menghasilkan impresi sebanyak 131,608 imperesi jauh lebih rendah dibandingkan \#BebaskaniBHRS dalam kurun waktu periode 2 Desember 2020- 1 Januari 2020, data yang diambil adalah dengan menggunakan 1000 tweet pada 13 Desember 2020 yang merupakan periode puncak percakapan dan keterlibatan. Peneliti mendapatkan gambaran bahwa pesan dan narasi yang ingin disampaikan dalam tagar ini adalah dukungan kepada pihak kepolisian, menunjukkan bentuk persetujuan atas tindakan kepolisian yang menangkap Riziq Shihab, pada 50 kata teratas dari sampel yang didapat sering kali para aktor menyampaikan pesan dengan menghubungkan aktor polisi dalam hal ini adalah @ divhumaspolri dan adanya tagar pendamping \#tnipolridanrakyatlawanfpi, katakata negatif seperti musnahkan dan basmi hal ini menunjukkan adanya mobilisasi kelompok yang menentang keberadaan FPI.

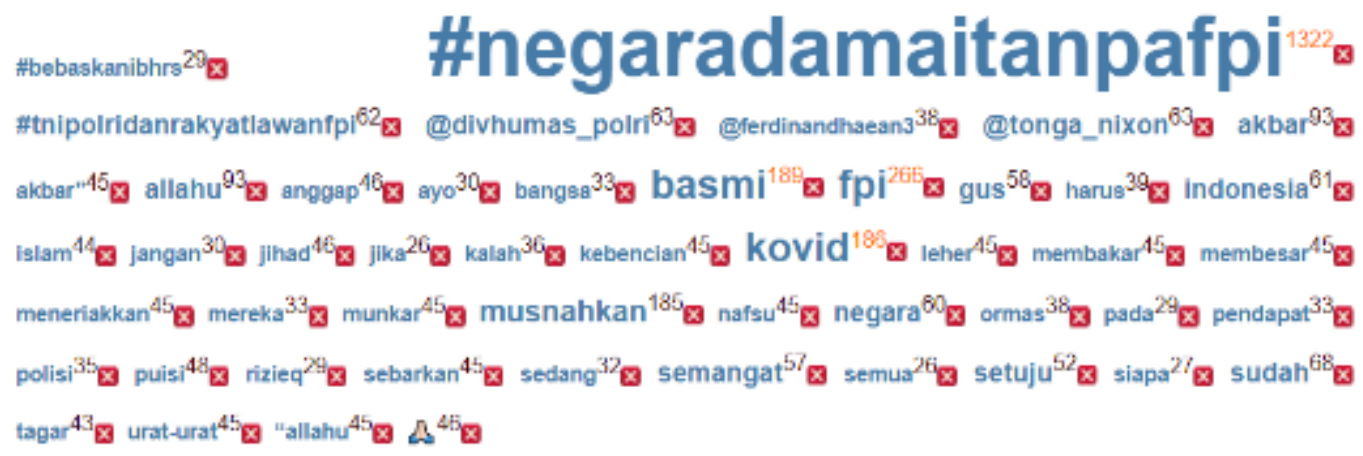

Gambar 6: 50 Kata teratas \#NegaradamaitanpaFPI (Sumber: Dokumentasi Peneliti) 
Berdasarkan analisis sintaksis konten pada 1000 tweet dalam tagar \#NegaradamaitanpaFPI menununjukan bahwa pesan komputasi propaganda berupa Flag-Waving, yaitu ditunjukkan melalui tagar penyerta yang mewakiliki populi sayap kanan \#tnipolridanrakyatlawanfpi, hal yang menarik adanya pesan komputasi propaganda loaded language yang dikemas dalam bentuk puisi yang diciptakan oleh Gus Mus yang berjudul "Allahu Akbar." Pada pesan komputasi propaganda Appeal to Authority sayap kanan sering kali menekankan bahwa kekuasaan ada pada tangan Polisi dan TNI. Slogan populi Islam Allahu Akbar sering kali disematkan dan menjadi kata dengan frekuensi teratas, pengalihan isu tentang COVID menjadi bagian dalam Whataboutism komputasi propaganda \#NegaradamaitanpaFPI.

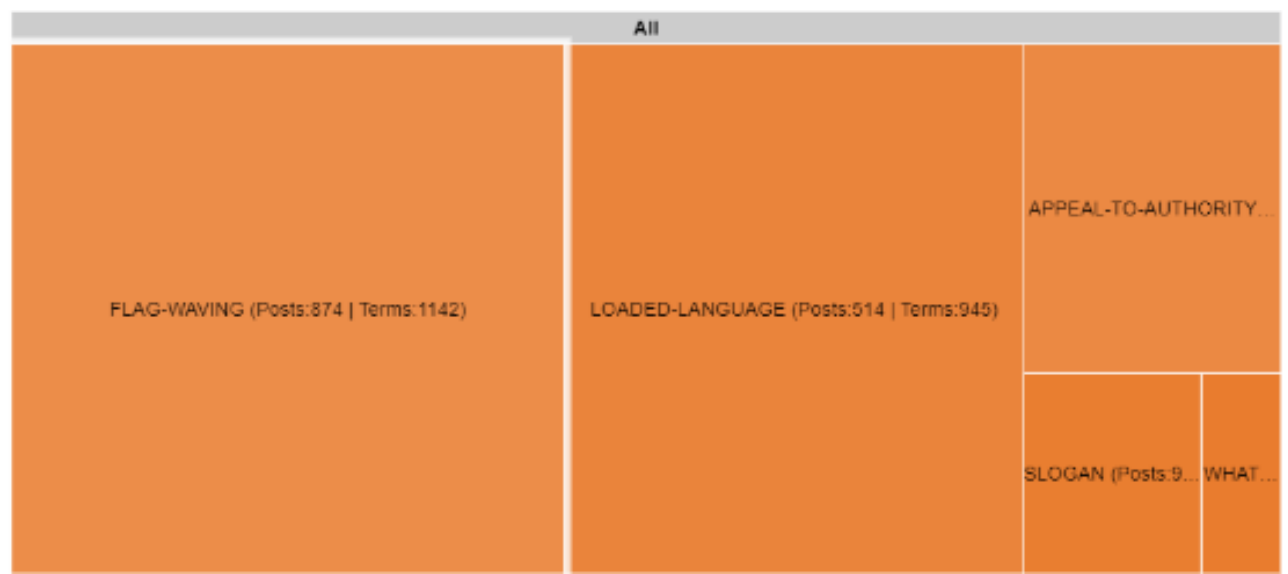

Gambar 7: Analisis sintaksis \#NegaradamaitanpaFPI

(Sumber: Dokumentasi Peneliti)

Pesan komputasi propaganda \#NegaradamaitanpaFPI dikoordinasikan melalui beberapa kelompok jaringan. Berdasarkan hasil analisis jaringan sosial mengungkapkan bahwa jaringan ini memiliki diameter 8 , hal ini berarti terdapat delapan langkah sebagai jarak paling jauh seorang aktor terhubung dengan aktor lain, hal ini mengindikasikan bahwa pesan \#NegaradamaitanpaFPI lebih sulit dicapai oleh anggota luar kelompok jika dibandingkan dengan \#BebaskaniBHRS. Nilai Density dalam struktur jaringan komunikasi ini memiliki nilai 0.004282 dan Repirocity 0.107100 kedua nilai ini mendekati nol, hal ini mengindikasikan bahwa interaksi antaraktor (akun media social) jaringan cenderung lemah dan komunikasi tidak dilakukan secara dua arah. Struktur jaringan ini memiliki nilai Centralization: 0.081180, nilai rendah pada Centralization mengindikasikan tidak adanya tokoh dominan (akun media sosial) yang secara langsung menyampaikan percakapan informasi kepada pengguna jaringan Twitter, 


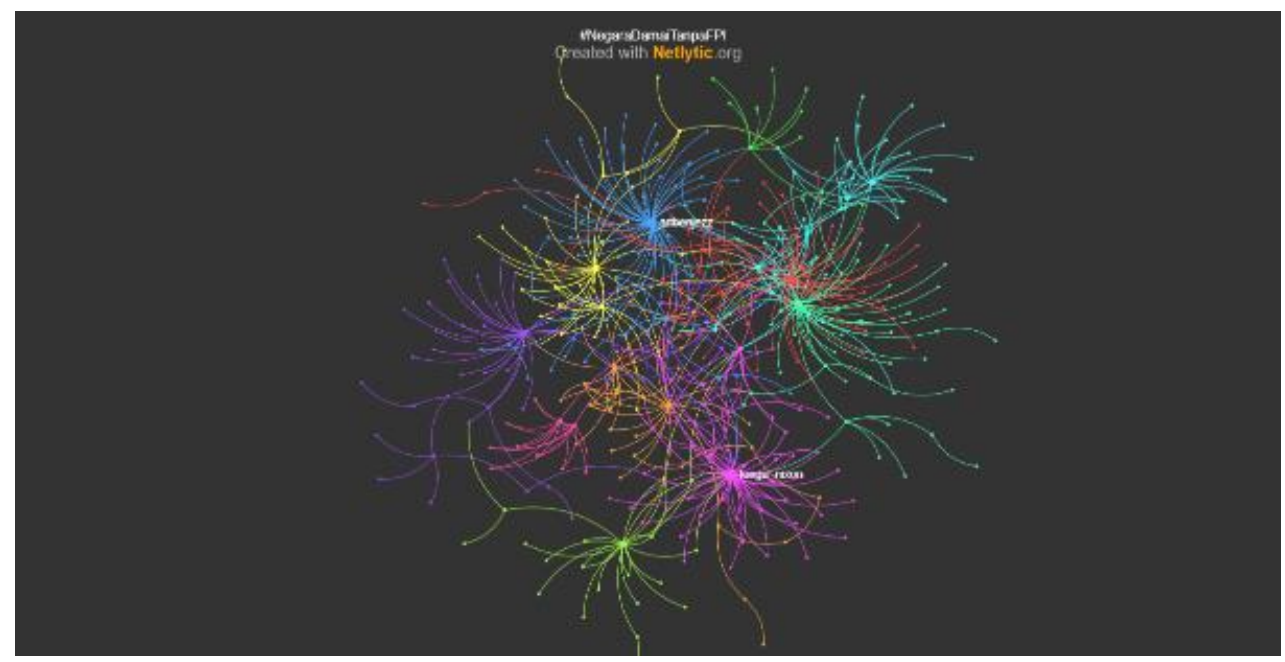

Gambar 8: Struktur Jaringan sosial \#NegaradamaitanpaFPI

(Sumber: Dokumentasi Peneliti)

Nilai modularity pada \#NegaradamaitanpaFPI adalah 0.746700 hal ini mengindikasikan adanya kelompok-kelompok besar di dalam jaringan. Kelompokkelompok ini dipimpin oleh akun-akun anonim yang menyebarluaskan gerakan \#NegaradamaitanpaFPI.
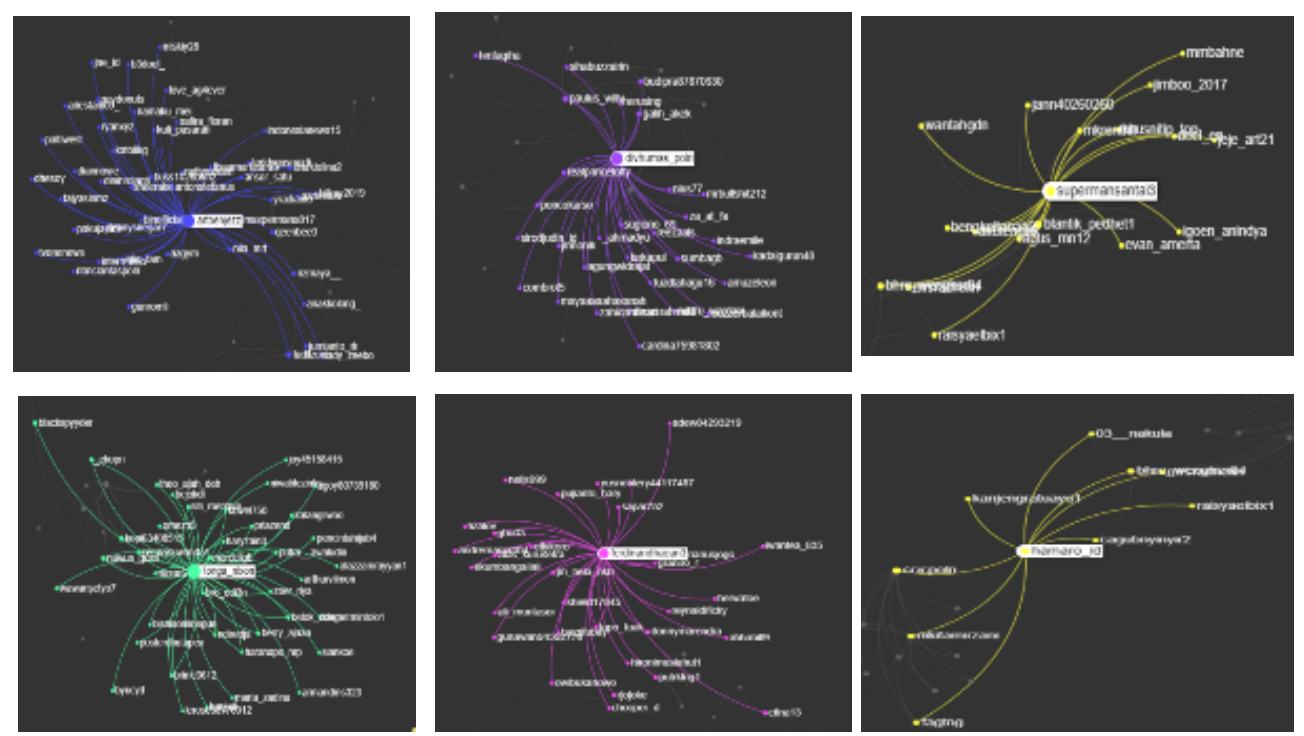

Gambar 9: Kelompok Jaringan sosial \#NegaradamaitanpaFPI(Sumber:Dokumentasi Peneliti)

Berdasarkan hasil analisis jaringan posisi akun maka dapat diketahui bawa akun-akun yang berpengaruh berpengaruh dalam penyebaran informasi, tokohtokoh ini secara aktif melakukan komunikasi keluar (outdegree) dengan tokoh lain, aktor-aktor seperti tonga_nixon dan artbenjezz adalah tokoh-tokoh yang sering menghubungkan diantara aktor satu dengan lain nya hal ini terindikasikan atas nilai betweenesscentrality yang cukup tinggi. Hal yang menarik adalah munculnya 
@divhumas_polri yang merupakan akun resmi Kepolisian Republik Indonesia yang sering dihubungkan oleh aktor-aktor lain.

Tabel 3. Aktor-aktor berpengaruh dalam struktur jaringan \#NegaradamaitanpaFPI

\begin{tabular}{|c|c|c|c|c|c|}
\hline $\begin{array}{l}\text { Akun media } \\
\text { sosial }\end{array}$ & $\begin{array}{c}\text { indegr } \\
e e\end{array}$ & $\begin{array}{c}\text { outdegre } \\
e\end{array}$ & $\begin{array}{c}\text { Degre } \\
e\end{array}$ & Centrality & betweenesscentrality \\
\hline tonga_nixon & 38 & 26 & 64 & 2 & 0,004247 \\
\hline artbenjezz & 1 & 52 & 53 & 2 & 0,000232 \\
\hline divhumas_polri & 46 & 0 & 46 & 0 & 0 \\
\hline $\begin{array}{c}\text { ferdinandhaean } \\
3\end{array}$ & 35 & 1 & 36 & 2 & 0,000171 \\
\hline ipw1078c & 1 & 26 & 27 & 7 & 0,000286 \\
\hline ariozatha & 1 & 25 & 26 & 5 & 0,000105 \\
\hline $\begin{array}{c}\text { bersamasahaba } \\
t 4\end{array}$ & 17 & 6 & 23 & 4 & 0,001636 \\
\hline lonelynobodys & 1 & 19 & 20 & 5 & 0,000576 \\
\hline $\begin{array}{c}\text { supermansantai } \\
3\end{array}$ & 0 & 18 & 18 & 5 & 0 \\
\hline santorinissun & 14 & 3 & 17 & 4 & 0,000779 \\
\hline ney_4pu3 & 5 & 12 & 17 & 6 & 0,000808 \\
\hline
\end{tabular}

Untuk membuktikan adanya akun politik yang memobilisi akun-akun lain dalam jaringan peneliti mengambil sampel jaringan dari akun penghubung terpenting dalam jaringan yang yang dibuktikan melalui nilai betweenesscentrality tertinggi, yaitu tonga_nixon. Berdasarkan hasil dari Botometer mengungkapkan bahwa tonga_nixon memiliki nilai Echo-chamber tinggi 2.9 yang mengindikasikan bahwa akun ini sering kali menyampaikan dan menyebarkan pesan-pesan politik dengan volume besar.

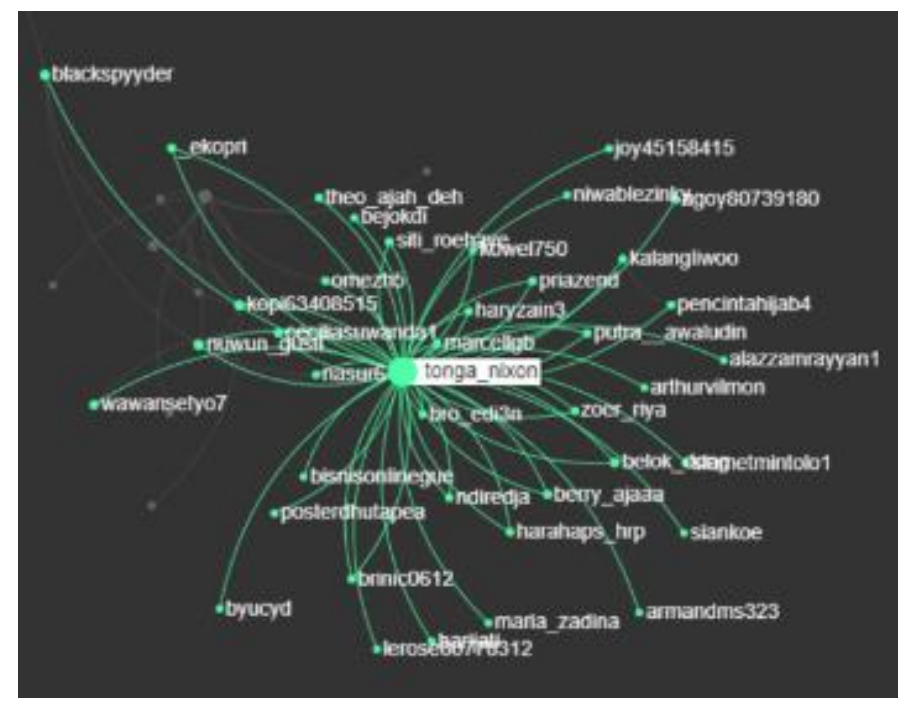

Gambar 10: akun politik masif \#NegaradamaitanpaFPI (Sumber: Dokumentasi Peneliti) 
Andhika Kurniawan Pontoh:

Computational Propaganda in Hashtag Activism

Komputasi Propaganda dalam Aktivisme Tagar

Untuk membuktikan adanya akun bot dalam jaringan \#NegaradamaitanpaFPI peneliti menambil sampel pesan komputasi propaganda loaded language berupa dukungan emosi berupa menyebarkan puisi karya Gus Mus.

Tabel 3. Akun-akun bot dalam struktur jaringan \#NegaradamaitanpaFPI

\begin{tabular}{|c|c|c|c|c|}
\hline Akun & Pesan Komputasi Propaganda & $\begin{array}{c}\text { Rasio } \\
\text { Retwe } \\
\text { et }\end{array}$ & $\begin{array}{c}\text { Nilai } \\
\text { Botomet } \\
\text { er }\end{array}$ & $\begin{array}{c}\text { Interpret } \\
\text { asi }\end{array}$ \\
\hline Egi33649032 & $\begin{array}{l}\text { RT @Rizmaya_: Sebarkan } \Omega \\
\text { Puisi Gus Mus: "Allahu Akbar" }\end{array}$ & $100 \%$ & 4.8 & $\begin{array}{c}\text { Akun } \\
\text { Bot }\end{array}$ \\
\hline$@ \log 0590$ & \multirow{3}{*}{$\begin{array}{c}\text { Allahu Akbar.! } \\
\text { Urat-Urat Leher Kalian Membesar } \\
\text { Meneriakkan Allahu Akbar \&amp; } \\
\text { Dengan... }\end{array}$} & $30 \%$ & 4.6 & $\begin{array}{c}\text { Akun } \\
\text { Bot }\end{array}$ \\
\hline $\begin{array}{l}\text { @andremania } \\
304\end{array}$ & & $94 \%$ & 4 & $\begin{array}{c}\text { Akun } \\
\text { Bot }\end{array}$ \\
\hline @ @acheenk_um & & $80 \%$ & 4.1 & $\begin{array}{c}\text { Akun } \\
\text { Bot }\end{array}$ \\
\hline
\end{tabular}

Pencapaian tren agar \#BebaskaniBHRS dan \#NegaradamaitanpaFPI telah diliput oleh media arus utama sehingga mampu menggaungkan impresi terhadap pesan narasi \#BebaskaniBHRS dan \#NegaradamaitanpaFPI hal ini menjadi sebuah ironi mengingat seharusnya media mainstream seharusnya menginformasikan nilai berita yang berdasarkan data dan sumber informasi yang valid. Media massa yang menjadi pengikut media sosial, negativitas media sosial justru dipublikasikan oleh media massa, khususnya media daring dan televisi dengan pola penyajian informasi spontan,serba cepat dan instan, akibatnya adanya ketidakberimbangan dalam berita (Sudibyo, 2019).
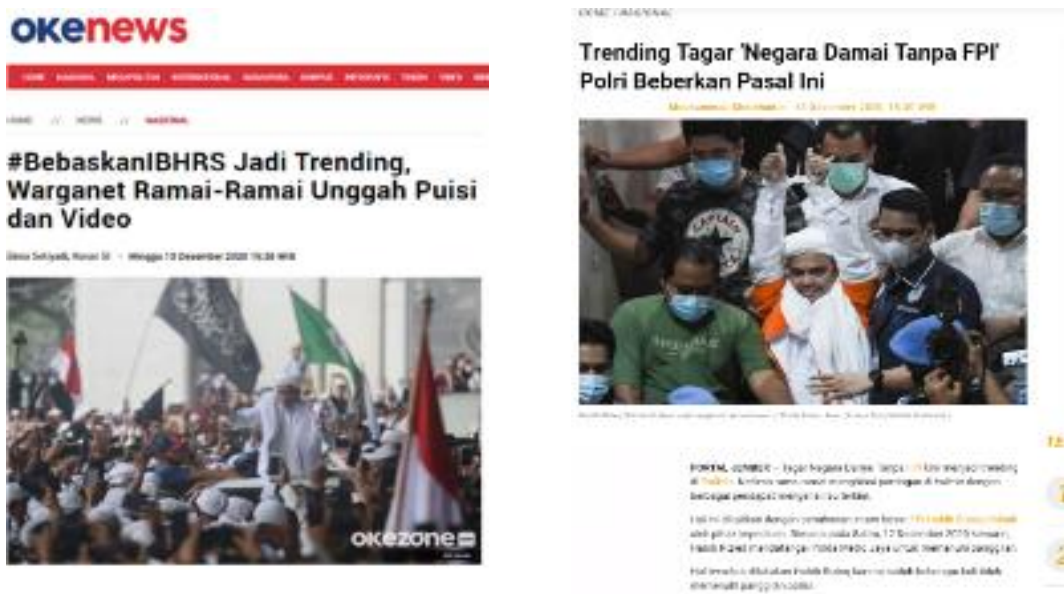

Gambar 10: Berita daring aktivisme tagar (Sumber: Dokumentasi Peneliti) 
Aktivisme tagar yang merupakan bentuk gerakan diskursif di media sosial yang disatukan melalui kata, frasa, atau kalimat yang diberi tagar yang mampu menciptakan wacana publik. Aktivisme tagar terjadi ketika adanya unggahan dengan jumlah banyak di media sosial yang memiliki kata atau kalimat tagar yang sama, tagar tersebut memiliki nilai-nilai sosial maupun politis (Tombleson \& Wolf, 2017). Wacana atau isu yang dimediasi secara digital dapat diasosiasikan sebagai cerminan mobilisasi dalam aksi politik offline (Polletta \& Lee, 2006). Penelitian tentang aktivisme digital telah berfokus pada karakter jaringan dan ikatnya (W. L. Bennett \& Segerberg, 2013). Aktivisme tagar \#BebaskaniBHRS memiliki kekuatan yang lebih besar dan cenderung stabil jika dibandingkan dengan \#BebaskaniBHRS kata-kata positif berupa dukungan dan doa yang disertai dengan poster propaganda dukungan, hal ini mampu menggugah emosi warganet untuk dapat terpapar dan terlibat dalam pesan komunikasi \#BebaskaniBHRS , hal ini dibuktikan dengan nilai diameter yang lebih kecil dibandingkan dengan \#NegaradamaitanpaFPI.

Tabel 3. Perbandingan Hasil Analisis Jaringan

\begin{tabular}{lcc}
\hline Nilai Jaringan & \#BebaskaniBHRS & \#NegaradamaitanpaFPI \\
\cline { 2 - 3 } Diameter & 4 & 8 \\
Density & 0.008831 & 0.004282 \\
Reciprocity & 0.000000 & 0.107100 \\
Centralization & 0.184400 & 0.081180 \\
Modularity & 0.514000 & 0.741700 \\
Unique Poster & 510 & 499 \\
\hline
\end{tabular}

Pada tabel perbandingan analisis Jaringan menunjukkan jika \#BebaskaniBHRS jauh lebih mudah dijangkau oleh akun-akun lain hal ini dibuktikan dengan nilai diameter yang lebih rendah. Berdasarkan nilai density menunjukkan jaringan \#BebaskaniBHRS cenderung lebih rapat jika dibandingkan dengan \#NegaradamaitanpaFPI. Komunikasi dua arah cenderung ditemukan pada \#NegaradamaitanpaFPI hal ini ditunjukkan dengan nilai Reciprocity yang lebih tinggi. \#BebaskaniBHRS memiliki akun-akun dominan yang memengaruhi jaringan jika dibandingkan dengan \#NegaradamaitanpaFPI hal ini dibuktikan dengan nilai Centralization yang lebih tinggi. \#BebaskaniBHRS lebih terdesentralisasi dibandingkan dengan \#NegaradamaitanpaFPI hal ini dibuktikan dengan nilai Modularity yang lebih rendah.

Pada aktivisme tagar \#BebaskaniBHRS terdapat ajakan untuk melakukan retweet pada beberapa pesan komunikasi politik \#BebaskaniBHRS hal ini juga mengakibatkan impresi yang jauh lebih besar daripada \#NegaradamaitanpaFPI. Berdasarkan hasil analisis peneliti menggunakan alat analisis Mediatoolkit mengungkapkan \#BebaskanIBHRS mampu menghasilkan impresi sebanyak 1,370,501 imperesi dan \#NegaraDamaiTanpaFPI hanya mampu menghasilkan impresi sebanyak 131,608 Impresi di Twitter, pada figur analisis komparasi menunjukkan \#NegaraDamaiTanpaFPI memiliki jumlah percakapan Twitter (mentions) lebih banyak pada tanggal 13 Desember 2020 dibandingkan dengan \#BebaskanIBHRS, namun secara periode satu bulan \#BebaskanIBHRS memiliki jumlah mentions lebih stabil dan mampu mempertahankan popularitasnya pada 
periode 2 Desember 2020- 1 Januari 2021. Keberhasilan tagar \#BebaskaniBHRS dalam memobilisasi publik di Twitter juga dipengaruhi oleh pemilihan kata dan narasi, kata "bebaskan" merupakan kata berupa ajakan langsung yang mampu membangkitkan emosi dibandingkan dengan \#NegaradamaitanpaFPI memiliki kata dengan jumlah yang panjang.

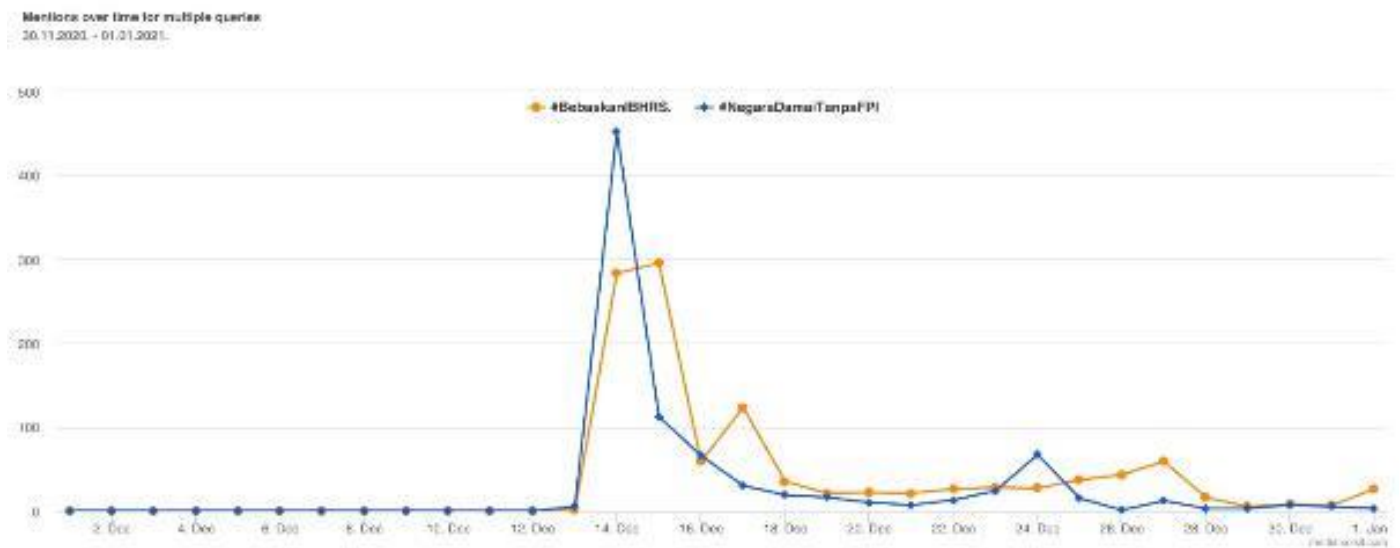

Gambar 12: Perbandingan impresi aktivisme tagar (Sumber: Mediatoolkit)

Keberhasilan \#BebaskaniBHRS dalam memobilisasi khalayak twitter dipengaruhi oleh beberapa faktor Pemilihan kata dan narasi dalam gerakan di media sosial juga telah diteliti sebelumnya oleh (Barisione et al., 2019) di mana tagar yang sukses adalah tagar yang memiliki bingkai yang jelas, (Eriyanto,2020). Dalam penelitian Digital Movement Opinion \#BubarkanKPAI vs \#KamiBersamaKPAI juga mengungkapkan pemilihan kata \#BubarkanKPAI memiliki frame yang jelas dibandingkan dengan \#KamiBersamaKPAI, hal ini memengaruhi kesuksesan tagar dalam memobilisasi publik. Penelitian lain juga menegaskan bahwa pemilihan kata mengajak khalayak twitter dalam perang tagar pemilihan presiden Indonesia 2019 mampu memobilisasi publik (Fitriana et al., 2020).

Aktivisme pada tagar Aktor-aktor yang terlibat dalam jaringan cenderung homogen di mana para aktor saling mendukung pesan-pesan pada tagar \#BebaskaniBHRS dan \#NegaradamaitanpaFPI. Karena sifatnya memperoleh dukungan, maka aktor-aktor harus melakukan mobilisasi aktor lain agar pesan melalui tagar dapat tersampaikan dengan baik. Akun media sosial palsu dan akun media sosial politik anonim adalah alat penting dalam serangan propaganda digital dan aktivitas ini merupakan bentuk dari kurasi manusia untuk dengan sengaja mendistribusikan informasi yang menyesatkan melalui jaringan media sosial, dengan harapan dapat memengaruhi percakapan, menggerakkan oposisi, menghasilkan dukungan palsu dan melakukan manipulasi opini publik.

Gerakan aktivisme digital \#BebaskaniBHRS dan \#NegaradamaitanpaFPI adalah bentuk respons mobilisasi aktor-aktor digital terhadap isu politik di dunia nyata terhadap kasus penyerahan diri Habib Riziq Shihab kepada kepolisian. Peneltian ini menemukan bahwa \#BebaskaniBHRS dan \#NegaradamaitanpaFPI sama-sama dimobilisasi oleh akun politik secara masif menyebarluaskan aktivisme agar. Gerakan BebaskaniBHRS dan \#NegaradamaitanpaFPI kemudian digaungkan secara automasi oleh akun-akun bot. 


\section{Simpulan}

Komputasi propaganda dalam aktivisme tagar \#BebaskaniBHRS dan \#NegaradamaitanpaFPI dapat terjadi akibat adanya akun politik anonim/akun palsu yang secara terstruktur desentralisasi memobilisasi pesan dengan aktor palsu antarjaringan. Keberhasilan mobilisasi \#BebaskaniBHRS dibandingkan \#NegaradamaitanpaFPI dapat terjadi dikarenakan pesan komputasi propaganda \#BebaskaniBHRS memiliki narasi bingkai yang jelas berupa ajakan secara langsung, pilihan kata yang mampu membangkitkan emosi serta aktor-aktor anonim dalam \#BebaskaniBHRS lebih aktif dalam memobilisasi dibandingkan \#NegaradamaitanpaFPI. Penelitian ini juga menyimpulkan bahwa gerakan automasi bot komputasi propaganda sering kali terlihat melalui duplikasi pesan atau retweet sehingga mampu menghasilkan impresi besar dan dijangkau oleh khalayak Twitter.

Berdasarkan keterbatasan peneliti merekomendasikan untuk adanya penelitian lebih lanjut dan lebih mendalam pada kelompok-kelompok akun anonim serta bot dalam aktivisme komputasi propaganda melalui metode netnografi media sosial sehingga diharapkan menghasilkan gambaran lebih luas tentang relasi kelompok komputasi propaganda. Berdasarkan temuan, peneliti merekomendasikan kepada media daring nasional untuk tidak menggaungkan tren tagar komputasi propaganda agar impresi pesan propaganda negatif tidak sampai pada publik secara luas sehingga mampu menjaga iklim politik yang kondusif.

\section{Daftar Pustaka}

Arnaudo, D. (2017). Computational propaganda in Brazil: Social bots during elections. In Project on Computational Propaganda (No. 8). Computational Propaganda Research Project. DOI:10.1093/oso/9780190931407.003.0007

Barisione, M., Michailidou, A., \& Airoldi, M. (2019). Understanding a digital movement of opinion: the case of\# RefugeesWelcome. Information, Communication \& Society, 22(8), 1145-1164. https://doi.org/10.1080/1369118X.2017.1410204

Bennett, J. (2014). Behold the power of\# tagar feminism. TIME. Com.

Bennett, W. L., \& Segerberg, A. (2013). The logic of connective action: Digital media and the personalization of contentious politics. Cambridge University Press. https://doi.org/10.1080/1369118X.2012.670661

BREIGER, R. L. (2004). Handbook of Data Analysis. SAGE Publications, Ltd. https://doi.org/10.4135/9781848608184

Castells, M. (2015). Networks of outrage and hope: Social movements in the Internet age. John Wiley \& Sons.

Chu, Z., Gianvecchio, S., Wang, H., \& Jajodia, S. (2010). Who is tweeting on Twitter: human, bot, or cyborg? Proceedings of the 26th Annual Computer Security Applications Conference, 21-30. https://doi.org/10.1145/1920261.1920265

Da San Martino, G., Cresci, S., Barrón-Cedeño, A., Yu, S., Di Pietro, R., \& Nakov, P. (2020). A survey on computational propaganda detection. ArXiv E-Prints, 
arXiv-2007.

Del Vicario, M., Bessi, A., Zollo, F., Petroni, F., Scala, A., Caldarelli, G., Stanley, H. E., \& Quattrociocchi, W. (2016). The spreading of misinformation online. Proceedings of the National Academy of Sciences, 113(3), 554-559. https://doi.org/10.1073/pnas.1517441113

Eriyanto, E. (2014). Analisis Jaringan Komunikasi. In Jakarta: Kencana.

Eriyanto, E. (2020). Tagars and Digital Movement of Opinion Mobilization: A Social Network Analysis/SNA Study on\# BubarkanKPAI vs\# KamiBersamaKPAI Tagars. Jurnal Komunikasi Indonesia, 167-178. https://doi.org/10.7454/jki.v8i3.11591

Fitriana, A., Ema, E., \& Lubis, F. O. (2020). Perang Tagar Di Ruang Virtual Diskursus Politik Capres Pasca Debat Putaran Kedua. Jurnal Komunikasi, 12(1), 30-52. http://dx.doi.org/10.24912/jk.v12i1.5622

Fitton, L., Gruen, M., \& Poston, L. (2010). Twitter for dummies. John Wiley \& Sons.

Gerbaudo, P. (2012). Tweets and the streets: Social media and contemporary activism. Pluto Press.

González-Bailón, S., Wang, N., Rivero, A., Borge-Holthoefer, J., \& Moreno, Y. (2014). Assessing the bias in samples of large online networks. Social Networks, 38, 16-27. http://dx.doi.org/10.1016/j.socnet.2014.01.004

Gorwa, R. (2017). Computational propaganda in Poland: False amplifiers and the digital public sphere. doi: 10.1093/oso/9780190931407.003.0005

Gruzd, A. (2016). Netlytic: Software for automated text and social network analysis. Diakses Dari Http://Netlytic. Org.

Hallahan, K. (1999). Seven models of framing: Implications for public relations. Journal of Public Relations Research, 11(3), 205-242. https://doi.org/10.1207/s1532754xjprr1103_02

Holtzhausen, D. R. (2009). Activism. In The future of excellence in public relations and communication management (pp. 383-406). Routledge.

Hootsuite, W. A. S. (2020). Digital 2020. Indonesia. Hootsuite, United State.

Lokot, T., \& Diakopoulos, N. (2016). News Bots: Automating news and information dissemination on Twitter. Digital Journalism, 4(6), 682-699. https://doi.org/10.1080/21670811.2015.1081822

Neudert, L.-M. N. (2017). Computational propaganda in Germany: A cautionary tale. Computational Propaganda Reserach Project, Paper, 7, 2017. DOI:10.1093/oso/9780190931407.003.0008

Polletta, F., \& Lee, J. (2006). Is telling stories good for democracy? Rhetoric in public deliberation after 9/11. American Sociological Review, 71(5), 699721. http://dx.doi.org/10.1177/000312240607100501

Sayyadiharikandeh, M., Varol, O., Yang, K.-C., Flammini, A., \& Menczer, F. (2020). Detection of novel social bots by ensembles of specialized classifiers. Proceedings of the 29th ACM International Conference on Information \& Knowledge Management, 2725-2732. https://doi.org/10.1145F3340531.3412698 
Setiyadi, B. (2020). \#BebaskanIBHRS Jadi Trending, Warganet Ramai-Ramai Unggah Puisi dan Video. Okezone.Com. https://nasional.okezone.com/read/2020/12/13/337/2326854/bebaskanibhrs -jadi-trending-warganet-ramai-ramai-unggah-puisi-dan-video

Sholehudin, M. (2020). Trending Tagar "Negara Damai Tanpa FPI" Polri Beberkan Pasal Ini. Pikiran Rakyat. https://portaljember.pikiranrakyat.com/nasional/pr-161102736/trending-tagar-negara-damai-tanpa-fpipolri-beberkan-pasal-ini

Small, T. A. (2011). What the tagar? A content analysis of Canadian politics on Twitter. Information, Communication \& Society, 14(6), 872-895. https://doi.org/10.1080/1369118X.2011.554572

Sudibyo, A. (2019). Jagat Digital: Pembebasan dan Penguasaan. Kepustakaan populer gramedia.

Tombleson, B., \& Wolf, K. (2017). Rethinking the circuit of culture: How participatory culture has transformed cross-cultural communication. Public Relations Review, 43(1), 14-25. http://doi.org/10.1016/j.pubrev.2016.10.017

Vis, F. (2014). The rapid spread of misinformation online. Outlook on the Global Agenda 2014.

Woolley, S. C., \& Howard, P. N. (2016). Automation, algorithms, and politics| political communication, computational propaganda, and autonomous agents - Introduction. International Journal of Communication, 10, 9.

Xiong, Y., Cho, M., \& Boatwright, B. (2019). Tagar activism and message frames among social movement organizations: Semantic network analysis and thematic analysis of Twitter during the\# MeToo movement. Public Relations Review, 45(1), 10-23. https://doi.org/10.1016/j.pubrev.2018.10.014

Zhang, J, Zhang, R., Zhang, Y., \& Yan, G. (2018). The Rise of Social Botnets: Attacks and Countermeasures. IEEE Transactions on Dependable and Secure Computing, 15(6), 1068-1082. https://doi.org/10.1109/TDSC.2016.2641441

Zhang, Junlong, \& Luo, Y. (2017). Degree centrality, betweenness centrality, and closeness centrality in social network. Proceedings of the 2017 2nd International Conference on Modelling, Simulation and Applied Mathematics (MSAM2017), 300-303. https://dx.doi.org/10.2991/msam-17.2017.68 